\title{
Transorbitomaxillaris percutan endoszkópos gastrostomia
}

\author{
Pap István dr. ${ }^{1}$ - Jakab-Péter Kinga dr. ${ }^{1}$ \\ Uzsaly János dr. ${ }^{1}$. Tóth István dr. ${ }^{1}$ - Barabás Márta-Andrea dr. ${ }^{3}$ \\ Fábián György dr. ${ }^{2}$ - Lujber László dr. ${ }^{1}$
}

\author{
${ }^{1}$ Pécsi Tudományegyetem, Általános Orvostudományi Kar, Klinikai Központ, Fül-, Orr-, Gégészeti és Fej-, \\ Nyaksebészeti Klinika, Pécs \\ ${ }_{2}^{2}$ Pécsi Tudományegyetem, Általános Orvostudományi Kar, Klinikai Központ, \\ II. Belgyógyászati Klinika és Nephrológiai, Diabetológiai Centrum, Pécs \\ ${ }^{3}$ Dr. Fogolyán Kristóf Megyei Sürgősségi Kórház, Sepsiszentgyörgy, Románia
}

Fej-nyaki daganattal diagnosztizált és kezelt betegeknél a szájon keresztüli táplálás gyakran nem lehetséges vagy nehezítetté válik a kezelés valamelyik fázisában. A beteg enteralis táplálásának biztosítására tartós és hatékony megoldást kell nyújtanunk, erre megfelelő választás lehet a percutan endoszkópos gastrostomia. A fej-nyaki régióban a daganat elhelyezkedése, kiterjedtsége és a mütétek miatt megváltozott anatómiai viszonyok sokszor gátat szabnak a gasztroszkóp hagyományos, szájon át történő sikeres levezetésének, és így különleges megoldásokra lehet szükség. Közleményünkben egy, a szakirodalomban is ritkán alkalmazott percutan endoszkópos gastrostomakészítésról számolunk be. A bemutatott esetben egy kiterjedt, rosszindulatú fej-nyaki daganat miatt totális maxillectomián és orbitaexenteratión átesett betegben a mútét következtében kialakult arcdefektuson át történt a gastroscopia és a tápszonda levezetése, ugyanis komplett szájzár következtében a beteg a táplálkozásra képtelen volt. A fent említett módszerrel sikerült a beteg hosszú távú enteralis táplálását megoldani minimálinvazív módon. Az összetett kóros esetek gyakran állítják kihívások elé a gyakorló klinikust. Esetbemutatásunkkal szeretnénk felhívni a figyelmet a hagyományos, megszokott módszerek helyett sokszor nagyobb sikerrel alkalmazható, személyre szabott terápiás lehetőségekre.

Orv Hetil. 2022; 163(3): 116-119.

Kulcsszavak: fej-nyaki tumor, maxillectomia, orbitalis exenteratio, transfacialis, percutan endoszkópos gastrostomia

\section{Transorbito-maxillary percutaneous endoscopic gastrostomy}

Peroral, enteral feeding is often impossible in patients with head and neck cancer. Percutaneous endoscopic gastrostomy is a well-established, quick, minimally invasive, and safe procedure for providing long-term enteral feeding. Space-occupying tumour mass and altered anatomy due to surgery inhibit the gastroscope's peroral introduction and the feeding tube's placement in some instances. Various access routes and modified insertion techniques are recommended to overcome the feeding tube insertion challenges. We present a rare case of a 64-year-old head and neck cancer patient who was unable to eat orally due to trismus and had a facial soft tissue defect following total maxillectomy and orbital exenteration. A complete oesophago-gastro-duodenoscopy and feeding tube insertion were performed transfacially. Percutaneous endoscopic gastrostomy was successful and uneventful via the maxillary and orbital soft tissue facial defect. No complication was noted, and long-term enteral feeding of the patient was provided in a minimally invasive way. Surgeons often face challenging cases when treating patients with head and neck cancer. The modification of standard procedures is sometimes required to adapt surgical techniques to the patient's specific case.

Keywords: head and neck cancer, maxillectomy, orbital exenteration, transfacial, percutaneous endoscopic gastrostomy

Pap I, Jakab-Péter K, Uzsaly J, Tóth I, Barabás M-A, Fábián Gy, Lujber L. [Transorbito-maxillary percutaneous endoscopic gastrostomy]. Orv Hetil. 2022; 163(3): 116-119.

(Beérkezett: 2021. április 16.; elfogadva: 2021. június 14.) 


\section{Rövidítések}

$\mathrm{CT}=$ (computed tomography) komputertomográfia; $\mathrm{PEG}=$ percutan endoszkópos gastrostomia

\section{Esetismertetés}

Egy 64 éves férfi beteget 1 éve fennálló, bal oldali orrdugulással irányították centrumunkba. Anamnéziséből kiemelendő az egyoldali véres-vizes orrváladékozás, az arcfélduzzanat és a szemkönnyezés. Orrmelléküreg-CTvizsgálat történt, mely kiterjedt sinonasalis térfoglaló folyamatot írt le, a bal arcüregből kiindulva. Kiterjedését tekintve betört a buccalis és masticatorius térbe, illetve hátrafelé a canalis pterygopalatinust is infiltrálta. Az arcüreg felső falán, a szemgödör medialis falán és a kemény szájpadon csontdestrukciót okozott. Kivizsgálást követően a beteg panaszainak hátterében sinonasalis cT4a, cNl, cM0 stádiumú anaplasticus carcinomát igazoltunk.

Intézményünk onkológiai bizottságának döntése értelmében elsőként választott kezelésként a beteg kemoterápiában részesült, mellyel a daganat 30\%-os regresszióját sikerült elérni.

Ezt követően a betegnél teljes maxillectomia történt. A maxillacsont „en block” eltávolítása során észlelheto volt a medialis falnak az erodáltsága. A daganat a szemgödörbe és a rostasejtekbe is beterjedt. Kezdeti törekvésünk a daganat épben történő kimetszése volt, a szemgolyó megőrzése mellett.

A szövettani feldolgozás a reszekciós szélek érintettségét (Rl) mutatta. Az orbitaexenteratióval járó, ismételt

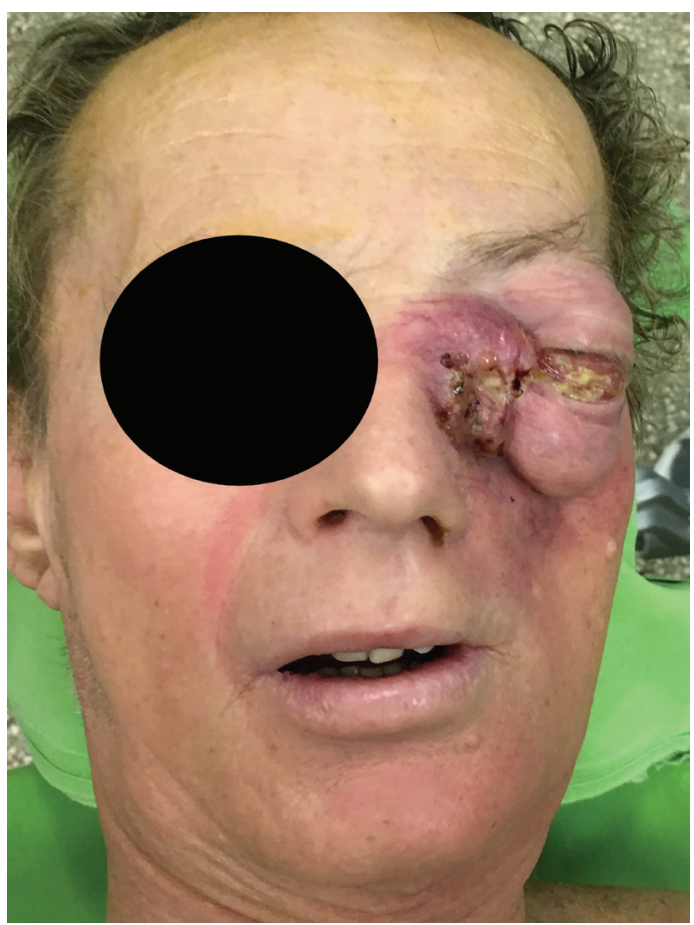

1. ábra A bal oldali orbitát, az orrmelléküregeket és az elülső koponya-
alapot infiltráló, exulcerált daganat mútéti beavatkozást a beteg ekkor elutasította, emiatt adjuváns kemoirradiáció mellett döntött az onkoteam.

A beteg 6 hónapig remisszióba került, de a kontrollvizsgálaton rapidan növekvő, a koponyaalapra törő daganatrecidívát észleltünk (1. ábra), mely miatt - a beteg beleegyezése után - kombinált fül-orr-gégészeti és idegsebészeti mútét, ún. craniofacialis reszekcó történt. A beavatkozás során a tumorrecidívát a szemgödör tartalmának exenteratiójával, az érintett lamina cribrosa területeinek komplett reszekciójával és az agyhártya kimetszésével tudtuk eltávolítani (2. ábra). Az agyhártya folytonosságának helyreállítására és az agyvízcsorgás megakadályozására duraplasticát végeztünk fascia lata lebennyel.

$\mathrm{Az}$ arcon keletkezett defektust fejtetőről forgatott nyeles galealebennyel zártuk. A posztoperatív időszakban jelentkezett asszociált gégebénulás miatt légcsőmetszés történt.

A gégebénulás hátterében nem igazolódott sem intracranialis, sem intrathoracalis metastasis. A beteg követése során, a korábbi forgatott lebeny helyén, a fülkagylón és egyéb arcterületeken disszeminált bőrmetastasisokat észleltünk (3. ábra). A cutan áttétek kimetszését - kizárólag palliatív célból - a beteg kérésére helyi érzéstelenítésben végeztük el. Miközben a beteg már palliatív célból sem részesült kemoterápiában, állapotában progressziót nem észleltünk, és a primer tumor területén recidíva nem jelent meg. Az orbitára és a maxillaris arcterületre forgatott galealebeny fokozatosan atrofizált, majd helyén lágyrészhiány alakult ki. Mindemellett közel egy év után fokozatosan kialakuló teljes szájzár miatt a beteg

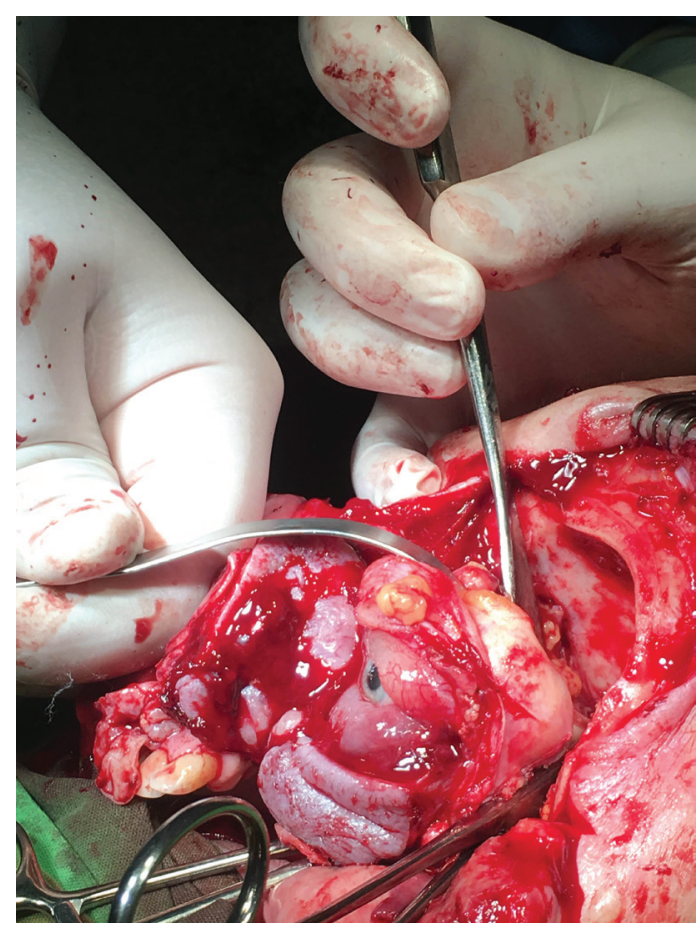

2. ábra Intraoperatíve készült fotó. Craniofacialis reszekció során „en
block” eltávolított daganat 


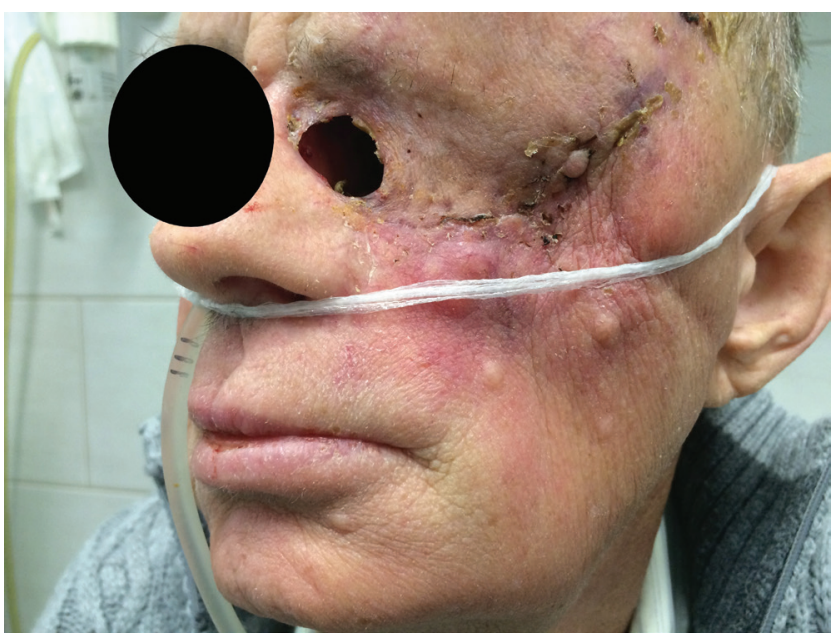

3. ábra | Bôrmetastasisok

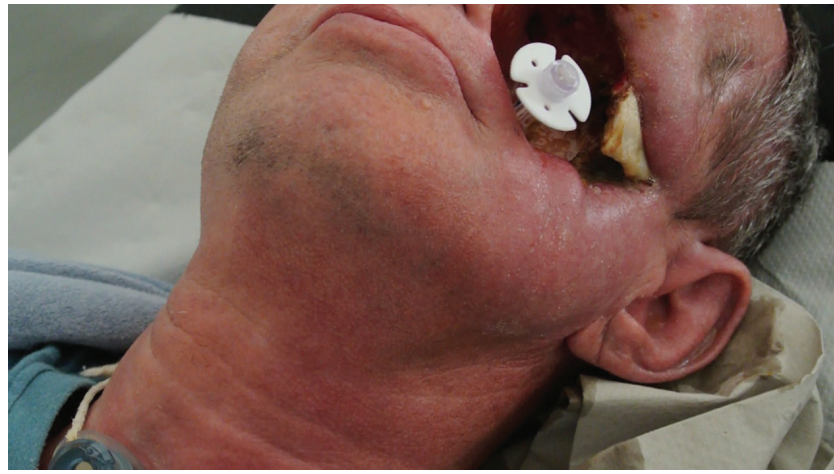

4. ábra

| Transorbitomaxillaris percutan endoszkópos gastrostoma készí-

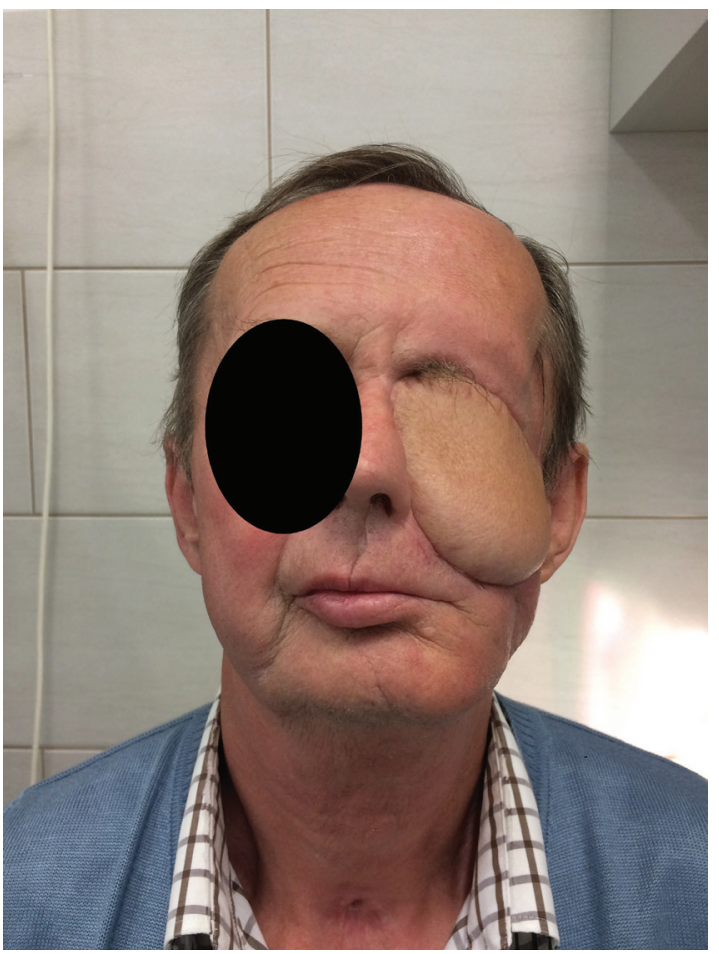

5. ábra

| A műtét után 6 hónappal készült fotó táplálkozása nasogastricus szondán át történt. Az arc plasztikai rekonstrukciója előtt PEG elvégzésének szükségessége merült fel, ezt azonban a hagyományos módon, szájon keresztül a fenti ok miatt nem tudtuk volna kivitelezni.

Tekintettel az eset egyediségére, különleges megoldást kellett találnunk. Mivel a korábbi szemgödör-exenteratio és teljes maxillectomia következtében kialakult szövethiány, közvetlenül a garatba vezetett, a gasztroszkóp bevezetését és így a szonda behelyezését transorbitomaxillarisan végeztük el, helyi érzéstelenítésben (4. ábra).

A beteg arcdefektusát és kemény szájpadjának hiányát musculus latissimus dorsi microvascularis izomlebennyel és az orrsövény porcos-csontos vázának forgatott kompozitlebenyével rekonstruáltuk, miközben ipsilateralisan az állcsonttest egy részét reszekálva oldottuk a beteg szájzárát is (5. ábra).

\section{Eredmények}

A gasztroszkóp bevezetése és a tápszonda behelyezése a teljes maxillectomia utáni üregen keresztül sikeres és jól kivitelezhető megoldásnak bizonyult. A beavatkozás során standard méretü gasztroszkópot és PEG-szereléket használtunk, és sem intraoperatív, sem posztoperatív szövődményeket nem észleltünk. A fenti módszerrel a beteg táplálása hosszú távon megoldódott, így a statisztikailag több szövődménnyel járó, nyitott hasi mütét nem vált szükségessé. A beteg rendszeres onkológiai és fül-orr-gégészeti kontrollvizsgálatok során 5 éve tumormentesnek bizonyult. Táplálkozása fóként PEG-szondán át zajlik, de időnként szájon át is eszik. Szájzára már csak részleges, és így beszéde jól érthető.

\section{Megbeszélés}

A fej-nyaki daganatos betegek több mint 40\%-ánál válik szükségessé tápszonda behelyezése a betegség valamelyik szakaszában, ezen betegek 4-7\%-ánál a transoralis PEG elvégzése nem kivitelezhető [1-3].

A technika négy évtizeddel ezelőtti első bevezetése óta a fej-nyaki daganatos betegek hosszan tartó mesterséges táplálása a leggyakrabban percutan endoszkópos gastrostomán át történik [4]. Biztonságos, gyors és minimálinvazív eljárás, a hagyományos nyitott sebészi gastrostomiával szemben [5]. A tápszonda percutan gyomorba rögzítése transoralisan végzett gasztroduodenoszkópia során lehetséges, azonban az előrehaladott stádiumban lévő fej-nyaki daganatok, radikális kiterjesztett mútétek és kiegészítő onkológiai kezelések hatására megváltozott anatómiai viszonyok miatt a fent említett eljárás lehetetlenné válik. Egyéb ellenjavallatot jelenthet a colon-interpozíció, a súlyos ascites, a morbid obesitas vagy az uralhatatlan coagulopathia $[2,3,6]$. A szakirodalomban korábban már számos műtéttechnikai változtatásról [710] és a gasztroszkóp bevezetésének alternatív útvonalairól közöltek módszereket [11]. Szúkítő térfoglalás ese- 
tén a PEG-et elvégezhetjük az orron át $[12,13]$, laringoszkóppal asszisztálva [14], meglévő nyaki sipolyokon át $[15,16]$, vagy a levezetés akadályát jelentő tumor eltávolításával egy időben a definitív mútéti ellátáskor [17]. Az általunk bemutatott eset különlegessége az, hogy az előzőekben említett alternatív módszerekkel sem lehetett percutan endoszkópos gastrostomát készíteni a tumoros folyamat és a mütétek okozta anatómiai és funkcionális eltérések miatt. Hasonló esetről Grier és mtsai számoltak be 1994-ben [18], amikor egy arcüreget érintő daganat mütéti ellátása során transmaxillaris behatoláson át végeztek PEG-et. A mi esetünkben a maxilloorbitalis régióban korábban kialakult lágyrészhiányon át vezettük be a gasztroszkópot és a tápszondát, a mútéti rekonstrukciót megelőzően. Ezzel a sebészi gastrostomát tudtuk kiváltani. Az eljárás technikájának a betegre és a betegségre szabott egyedi változtatásával ebben az esetben is sikerült a behelyezést elvégezni. Megórizhető volt a beavatkozás minimálinvazív jellege, annak ellenére, hogy nem a hagyományos, szájon át történő gyomorszonda-levezetés történt.

\section{Következtetés}

Az összetett kóros esetek gyakran állítják kihívások elé a gyakorló klinikust. Esetbemutatásunkkal szeretnénk felhívni a figyelmet a hagyományos, megszokott módszer helyett sokszor nagyobb sikerrel alkalmazható, személyre szabott terápiás lehetőségre, mely egyben a legkevésbé invazív megoldásnak is bizonyulhat.

Anyagi támogatás: A cikk megírása, illetve a kapcsolódó kutatómunka anyagi támogatásban nem részesült.

Szerzői munkamegosztás: A kézirat megszövegezése: P. I. $\mathrm{Az}$ irodalomkutatás elvégzése: J.-P. K., U. J., T. I., B. M.-A. Az eset diagnosztizálása és mütéti kezelése, a kutatómunka lefolytatása, a kézirat szakmai véleményezése: F. Gy., L. L., P. I. A cikk végleges változatát valamennyi szerző elolvasta és jóváhagyta.

Érdekeltségek: A szerző́knek nincsenek érdekeltségeik.

\section{Irodalom}

[1] Rahnemai-Azar AA, Rahnemaiazar AA, Naghshizadian R, et al. Percutaneous endoscopic gastrostomy: indications, technique, complications and management. World J Gastroenterol. 2014; 20: 7739-7751.

[2] Nugent B, Parker MJ, McIntyre IA. Nasogastric tube feeding and percutaneous endoscopic gastrostomy tube feeding in pa- tients with head and neck cancer. J Hum Nutr Diet. 2010; 23: 277-284.

[3] Gibson SE, Wenig BL, Watkins JL. Complications of percutaneous endoscopic gastrostomy in head and neck cancer patients. Ann Otol Rhinol Laryngol. 1992; 101: 46-50.

[4] Gauderer MW, Ponsky JL, Izant RJ Jr. Gastrostomy without laparotomy: a percutaneous endoscopic technique. J Pediatr Surg. 1980; 15: 872-875.

[5] Bravo JG, Ide E, Kondo A, et al. Percutaneous endoscopic versus surgical gastrostomy in patients with benign and malignant diseases: a systematic review and meta-analysis. Clinics (Sao Paulo) 2016; 71: 169-178.

[6] Molina Villalba C, Vázquez Rodríguez JA, Gallardo Sánchez F. Percutaneous endoscopic gastrostomy. Indications, care and complications. Med Clin (Barc) 2019; 152: 229-236.

[7] Lujber L, Pytel J. Second look endoscopy by a laryngo-fiberscope passed via the feeding tube of the percutaneous endoscopic gastrostomy. Surg Laparosc Endosc Percutan Tech. 2003; 13: 212-214.

[8] Lujber L, Pytel J. Second-look endoscopy during percutaneous endoscopic gastrostomy by passing a laryngofiberscope through the inserted feeding tube. Endoscopy 2003; 35: 885.

[9] Oricchio M, Taullard A, Álvarez D, et al. An unusual endoscopic approach to perform a percutaneous endoscopic gastrostomy. Adv Res Gastroentero Hepatol. 2020; 15: 555910.

[10] Cherian P, Blake C, Appleyard M, et al. Outcomes of radiologically inserted gastrostomy versus percutaneous endoscopic gastrostomy. J Med Imaging Radiat Oncol. 2019; 63: 610-616.

[11] Di Palma LD, Mello GF, Granados CL, et al. Pharyngocutaneous fistula as an alternative access route for inserting a percutaneous endoscopic gastrostomy tube in head and neck cancer patients. Endosc Int Open 2017; 5: E630-E634.

[12] Taller A, Horváth E, Harsányi L, et al. Transnasal percutaneous endoscopic gastrostomy. Endoscopy 1997; 29: 337.

[13] Nevah MI, Lamberth JR, Dekovich AA. Transnasal PEG tube placement in patients with head and neck cancer. Gastrointest Endosc. 2014; 79: 599-604.

[14] Taller A, Horváth E, Iliás L, et al. Technical modifications for improving the success rate of PEG tube placement in patients with head and neck cancer. Gastrointest Endosc. 2001; 54: 633636.

[15] Lujber L, Fábián G, Pytel J. Inserting a percutaneous endoscopic gastrostomy tube via a cervical fistula formed after major surgery on a patient with a head and neck tumor. Surg Laparosc Endosc Percutan Tech. 2001; 11: 327-329.

[16] Lujber L. Placement of a percutaneous endoscopic gastrostomy feeding tube via a cervical pharyngocutaneous fistula. Endoscopy 2006; 38(Suppl 2): E57.

[17] Lujber L, Saárossy K, Fábián Gy, et al. Percutaneous endoscopic gastrostomy: prae-, intra-, or postoperative insertion. [Percutan endoscopos gastrostomia: prae-, intra-, és postoperatív beültetés.] Fül-Orr-Gégegyógyászat 1999; 45: 7-13. [Hungarian]

[18] Grier JF, Goldman DE, Gholson CF. Transmaxillary percutaneous endoscopic gastrostomy. Gastrointest Endosc. 1994; 40: 778-779.

(Pap István dr., Pécs, Munkácsy M. u. 2., 7621 e-mail: pap.istvan@pte.hu)

A cikk a Creative Commons Attribution 4.0 International License (https://creativecommons.org/licenses/by/4.0/) feltételei szerint publikált Open Access közlemény, melynek szellemében a cikk bármilyen médiumban szabadon felhasználható, megosztható és újraközölhetö, feltéve, hogy az eredeti szerző és a közlés helye, illetve a CC License linkje és az esetlegesen végrehajtott módosítások feltüntetésre kerülnek. (SID_1) 